\title{
KOMPOSISI KIMIA DAN PROFIL ASAM LEMAK IKAN LAYUR SEGAR PENYIMPANAN SUHU DINGIN
}

\author{
Agoes Mardiono Jacoeb ${ }^{1}$, Nurjanah ${ }^{* 1}$, Taufik Hidayat ${ }^{2}$, Riyanda Perdiansyah ${ }^{1}$ \\ ${ }^{1}$ Departemen Teknologi Hasil Perairan, Fakultas Perikanan dan Ilmu Kelautan, Institut Pertanian Bogor \\ Institut Pertanian Bogor, Kampus IPB Darmaga, Jalan Agatis, Bogor 16680 Jawa Barat \\ Telepon (0251) 8622909-8622906, Faks. (0251) 8622915 \\ ${ }^{2}$ Pusat Teknologi Agroindustri, Badan Pengkajian dan Penerapan Teknologi, Gedung LAPTIAB 610 \\ Puspiptek Serpong \\ Korespodensi: inun_thp10@yahoo.com
}

Diterima: 1 Februari 2019/ Disetujui: 1 Februari 2020

Cara sitasi: Jacoeb AM, Nurjanah, Hidayat T, Perdiansyah R. 2020. Komposisi kimia dan profil asam lemak ikan layur segar penyimpanan suhu dingin. Jurnal Pengolahan Hasil Perikanan Indonesia. 23(1): 147-157.

\begin{abstract}
Abstrak
Ikan layur merupakan komoditas bahan baku ekspor bernilai ekonomis penting. Proses penyimpanan memengaruhi komposisi kimia ikan layur. Penelitian ini bertujuan menentukan pengaruh penyimpanan dingin terhadap perubahan komposisi kimia dan profil asam lemak ikan layur (Trichiurus sp.). Prosedur penelitian yang dilakukan adalah penyimpanan pada suhu dingin $6-10^{\circ} \mathrm{C}$ selama 0 hari $(\mathrm{H} 0)$ segar, 6 hari (H6) agak segar, dan 10 hari (H10) tidak segar. Ikan layur mengalami kenaikan kadar air dan lemak, sedangkan kadar protein dan kadar abu, mengalami perubahan. Hasil manunjukkan bahwa asam lemak secara umum tidak mengalami perubahan secara deskriptif selama penyimpanan dingin 10 hari. Ikan layur terdiri dari 24 jenis asam lemak yang terdiri dari 10 jenis SFA, 7 jenis MUFA, dan 7 jenis PUFA. Asam lemak tertinggi ikan layur yaitu DHA yaitu 24,01\% (H0) dan 21,39\% (H10).
\end{abstract}

Kata kunci: asam lemak, DHA, ikan layur (Trichiurus pepturus), komposisi kimia.

\section{Chemical Composition and Fatty Acid Profile in Hairtail Fish During Chilling Storage}

\begin{abstract}
The study was aimed to determine the effect of chilling temperature storage on the chemical composition and fatty acid profile of hairtail fish (Trichiurus lepepturus). The fish were stored at $6-10^{\circ} \mathrm{C}$ and were anlaysed at day $0(\mathrm{H} 0)$, day $6(\mathrm{H} 6)$, and day $10(\mathrm{H} 10)$. The moisture and fat content of the hartail fish were increased during chilling storage while the protein and ash were decreased. The fatty acid content of hairtail fish was changed during the 10 day storage period. The hairtail fish contained 24 types of fatty acids, 10 of SFA content, 7 of MUFA content, and 7 of PUFA content. The hairtail fish was found to contain high amount of DHA
\end{abstract}

Keywords: chemical composition, DHA, fatty acid, fish hairtail (Trichiurus lepepturus).

\section{PENDAHULUAN}

Ikan dapat menjadi sumber pangan utama yang dapat memenuhi kebutuhan gizi tubuh. Kandungan gizi protein, lemak, dan vitamin pada ikan mampu mencukupi kebutuhan gizi serta memberikan efek kesehatan bagi tubuh. Bagian ikan paling penting yang sering dihubungkan dengan kesehatan adalah minyak ikan. Produk ini mempunyai karakteristik asam lemak yang beragam mulai dari 12 sampai 26 atom karbon dan 0 sampai 6 ikatan rangkap. Asam lemak yang terkandung dalam ikan terdiri atas asam lemak jenuh $15 \%$ sampai $25 \%$, asam lemak 
tak jenuh tunggal 35\% sampai $60 \%$ dan asam lemak tak jenuh majemuk 25\% sampai $40 \%$ (Berghe dan Barnathan 2005).

Lemak terdiri dari ester trigliserida (TG) dari gliserol yang terkait rantai utama (Tuminah 2009). Fungsi lemak yaitu sumber energi, bagian dari membran sel, mediator aktivitas biologis antar sel, isolator dalam menjaga keseimbangan suhu tubuh dan pelindung organ (Almatsier 2006). Asam lemak merupakan unit dasar pembangun lemak yang sifatnya khas. Beberapa hasil penelitian menunjukkan bahwa asam lemak banyak terdapat pada ikan dan hasil perairan lainnya (Abdullah et al. 2013; Nurjanah et al. 2014; Abdullah et al. 2015). Salah satu ikan yang mempunyai asam lemak yang baik yaitu ikan layur.

Ikan layur banyak ditemukan pada wilayah beriklim tropis. Perairan India ditemukan ikan layur berat rata-rata 500-800 g memiliki total lemak $3,4 \%$ yang terdiri dari $42,1 \%$ saturated fatty acid (SFA), $28,7 \%$ mono unsaturated fatty acid (MUFA) dan 23,3\% poly unsaturated fatty acid (PUFA) (Mohanty et al. 2016). Ikan ini dikenal dengan nama ribbon fish yang merupakan salah satu ikan komersial penting dan memiliki prospek ekonomi yang tinggi. Ikan layur menjadi salah satu komoditas ekspor Indonesia ke berbagai negara besar di Asia. Ikan layur (Trichiurus lepturus sp.) menjadi salah satu ikan andalan dari sub sektor perikanan di wilayah Palabuhanratu, Sukabumi, Jawa Barat. Identifikasi berbasis DNA pada berbagai produk ikan layur di Palabuhanratu telah dilakukan untuk menghindari pemalsuan, hasil yang diperoleh bahwa produk teridentifikasi sebagai Trichiurus sp. dan T. lepturus dengan tingkat homologi 91-100\% (Abdullah et al. 2019). Produksi total hasil tangkapan layur di wilayah ini tercatat 90,30 ton pada tahun 2015 dengan nilai mencapai 2,19 milyar rupiah, sedangkan pada tahun 2017 mengalami penurunan hasil tangkapan sebesar 53,632 ton dengan nilai dibawa 1 milyar rupiah (PPN Palabuhan ratu 2018). Nilai ekspor ikan layur dunia pada tahun 2015 mengalami peningkatan dengan nilai yaitu US\$ 27,5 juta dari tahun 2014 yaitu US\$ 12 juta, dan kembali mengalami penurunan pada tahun 2017 sebesar US\$ 11 juta. Vietnam dan China menjadi negara yang menyumbangkan nilai impor paling besar dengan total nilai US\$ 25,1 juta dan US\$ 1,08 juta pada tahun 2017 (ITPC 2018).

Ikan juga termasuk kategori perishable food yang disebabkan oleh enzim yang aktif sesaat setelah ikan mengalami proses kematian. Penanganan ikan yang tidak tepat menyebabkan ikan akan mengalami pembusukan dalam waktu yang cepat (Hidayat 2015). Kemunduran mutu ikan tersebut akan menyebabkan komponen lemak dan asam lemak mengalami kerusakan (Arpaslan et al. 2012). Faktor penting dalam mencegah kerusakan ikan adalah suhu rendah dan waktu. Penggunaan es banyak dilakukan nelayan untuk memperlambat kemunduran mutu ikan.

Profil asam lemak bisa ditentukan dengan baik menggunakan suhu dingin dalam ekstraksi lemaknya. Metode Bligh Dyer merupakan salah satu metode ekstraksi dingin yang diperkirakan akan menghasilkan lemak yang profilnya lebih tepat (Nurjanah et al, 2015). Penelitian ini bertujuan menentukan pengaruh penyimpanan dingin terhadap perubahan komposisi kimia dan profil asam lemak ikan layur.

\section{BAHAN DAN METODE Bahan dan Alat}

Bahan baku yang digunakan pada penelitian ini adalah ikan layur (Trichiurus sp.) yang diambil dari Tempat Pelelangan Ikan (TPI) Palabuhanratu sebanyak 12 ekor dengan size $2,8 \mathrm{~kg}$. Bahan yang digunakan untuk analisis adalah akuades, katalis selenium, $\mathrm{H}_{2} \mathrm{SO}_{4}$ (Merck KGa), $\mathrm{H}_{3} \mathrm{BO}_{3}$ (Merck) 2\%, kertas saring, kapas bebas lemak, $\mathrm{HCl}$ (Merck) 0,1 (Merck) N, $\mathrm{NaOH}$ (Merck) $40 \mathrm{~mL}$, pelarut heksana (Sigma Aldrich), bromcresol green(Sigma) 0.1\%, dan methyl red 0,1\% (Sigma), akuades, kloroform dan metanol, $\mathrm{NaOH}$ (Merck) 0,5 N dalam metanol, $\mathrm{BF}_{3}$ (Merck), $\mathrm{NaCl}$ jenuh (Merck), n-heksana (Merck), dan $\mathrm{Na}_{2} \mathrm{SO}_{4}$ anhidrat (Merck). Alat yang digunakan untuk penelitian ini yaitu homogenizer (armfiled), evaporator (Eterna) dan kromatografi gas (Shimidzu GC 2010 Plus made in Japan) dengan standar SupelcoTM 37 
Component FAME Mix.

Identifikasi asam lemak dilakukan dengan menginjeksi metil ester pada alat kromatografi gas dengan kondisi sebagai berikut:

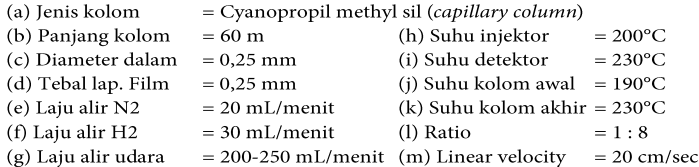

Waktu retensi dan puncak masing-masing asam lemak diukur lalu dibandingkan dengan waktu retensi standar untuk mendapatkan informasi mengenai jenis dan jumlah asam lemak dalam contoh. Kandungan asam lemak ikan tuna dihitung dengan rumus sebagai berikut:

$\%$ Asam lemak $=\frac{\frac{\text { luas area sampel }}{\text { luas area standar }} \times \mathrm{C} \text { standar } \mathrm{x} \frac{\mathrm{V} \text { contoh }}{100} \times 100 \%}{\text { Bobot contoh }}$

\section{Pengukuran morfometrik}

Proses pengukuran morfometrik mengacu pada Morales et al. (1998), diawali dengan menempatan ikan pada talenan dengan posisi kepala menghadap kiri. Pengukuran morfometrik dilakukan pada 7 sampel ekor ikan layur, berat ikan diukur dengan neraca analitik, sedangkan panjang dan tinggi ikan diukur menggunakan mistar dengan ketelitian $0,1 \mathrm{~cm}$. Parameter pengukuran yang dilakukan pada ikan layur adalah panjang total, panjang kepala, tinggi badan, dan lebar badan.

\section{Prosedur Penelitian}

Tahapan penelitian dimulai dengan proses preparasi ikan layur (Trichiurus sp.) yang meliputi pemisahan ukuran, pengukuran morfometrik dan rendemen bagian. Ikan layur dengan ukuran yang sama dimasukkan ke dalam stirofoam yang berukuran 70x30x30 $\mathrm{cm}$ dengan menggunakan plastik polietilen (PE) agar air dari es yang mencair tidak masuk. Perbandingan jumlah ikan dan es yang digunakan yaitu 1:3 dengan penambahan es setiap 12 jam sekali. Suhu di dalam stirofoam dijaga dengan cara menambahkan es setiap 12 jam sekali agar tetap pada suhu $6-10^{\circ} \mathrm{C}$ diukur menggunakan termometer alkolhol selama 10 hari. Pengamatan dilakukan selama 48 jam sekali dengan pengujian organoleptik berdasarkan scoresheet SNI 2729.2013 untuk mengetahui fase mortem ikan. Preparasi dan dilakukan pada ikan yang telah masuk rentang mortem. Daging fillet kemudian dicacah dan dihomogenkan. Tahap selanjutnya adalah analisis proksimat dan ekstraksi bligh dyer penyimpanan hari yang berbeda dari hari ke0, 6, dan 10. Hasil ekstraksi bligh dyer pada perlakuan penyimpanan hari ke-0 dan ke-10 dilakukan analisis lemak untuk menentukan perubahan profil asam lemak yang terjadi selama penyimpanan dingin.

\section{Analisis Proksimat}

Analisis proksimat yang dilakukan untuk menentukan komposisi kimia ikan layur. Analisis mengacu pada (AOAC 2005) meliputi kadar air, abu, lemak, dan protein. Perhitungan karbohidrat menggunakan by different.

\section{Perhitungan rendemen}

Rendemen rendemen merupakan perhitungan proporsi bobot ikan sebagai persentase bobot perbagian pada ikan. Perhitungan rendemen pada penelitian ini meliputi rendemen kepala, rendemen jeroan, rendemen tulang dan rendemen daging dan kulit. Rumus perhitungan rendemen yaitu:

$$
\text { Rendemen }(\%)=\frac{\text { Bobot contoh }(\mathrm{g})}{\text { Bobot total }(\mathrm{g})} \times 100 \%
$$

\section{Analisis asam lemak}

Analisis asam lemak mengacu pada AOAC (2005) diawali penyiapan $20 \mathrm{mg}$ ekstrak lemak sampel dalam tabung bertutup teflon, lalu dipanaskan dalam penangas air selama 20 menit. Tahap berikutnya adalah penambahan larutan $\mathrm{BF}_{3} 20 \% 2 \mathrm{~mL}$ dan $5 \mathrm{mg} /$ $\mathrm{mL}$ standar internal dan dipanaskan selama 20 menit. Campuran kemudian didinginkan dan ditambahkan $2 \mathrm{~mL} \mathrm{NaCl}$ jenuh dan $1 \mathrm{~mL}$ isooktan, lalu campuran dikocok dengan baik. Lapisan isooktan yang terbentuk dipindahkan dengan bantuan pipet tetes ke dalam tabung berisi sekitar 0,1 $\mathrm{g} \mathrm{Na}_{2} \mathrm{SO}_{4}$ anhidrat, dan dibiarkan 15 menit. Fasa cair yang terbentuk dipisahkan, sedangkan fasa minyak yang terbentuk diinjeksikan ke instrumen GC sebanyak $1 \mu \mathrm{L}$, setelah sebelumnya dilakukan penginjeksian $1 \mu \mathrm{L}$ campuran standar FAME (Supelco 37 component fatty acid methyl ester mix). 


\section{Analisis Data}

Data hasil pengujian diolah secara statistik deskriptif dan menggunakan Microsoft excel. Hasil olahan data kemudian dibandingkan dengan studi literatur.

\section{HASIL DAN PEMBAHASAN Morfometrik Ikan Layur}

Ikan layur (Trichiurus sp.) merupakan ikan karnivora dengan ciri-ciri berupa badan yang memanjang dan pipih dan tidak memiliki sisik (Abidin et al.2013; Vianita et al. 2014), panjang badan pada umumnya berkisar 50$100 \mathrm{~cm}$ dengan panjang maksimum mencapai 1,2 m; mulut lebar dan memiliki gigi rahang yang kuat, sirip pungung dimulai dari belakang kepala sampai ekor yang berjumlah satu buah, jumlah jari-jari sirip lunak berkisar 140-150 buah (Nakamura dan Parin 1993). Analisis morfometrik ikan layur pada penelitian ini melipui bobot total, panjang total, tinggi, lebar, dan panjang kepala. Gambar ikan layur ditunjukkan pada Figure1.

Bobot ikan layur rata-rata $250,14 \mathrm{~g}$. Panjang total dengan rata-rata $79,64 \mathrm{~cm}$, sedangkan lebar badan yaitu 1,91 cm (Table 1). Ikan layur dewasa memiliki panjang kepala 8 sampai $14 \mathrm{~cm}$ (Abidin et al. 2013) dan panjang tubuh ikan layur berkisar 20,3 sampai 97,5 $\mathrm{cm}$, dengan panjang tubuh ikan layur dewasa berkisar 70 sampai $100 \mathrm{~cm}$ (Prihatiningsih dan Nurulludin 2014). Muhammad et al. (2017) menjelaskan bahwa bobot tubuh ikan layur minimal $60 \mathrm{~g}$ sedangkan bobot maksimal dapat mencapai 2000 g. Perbedaan bobot ikan layur dapat ditentukan oleh faktor internal (umur, keturunan, penyakit, dan jenis kelamin) dan faktor eksternal (makanan, habitat, dan kualitas perairan) (Spikadhara et al. 2012). Ikan layur konsumsi yang diekspor memiliki rata-rata berat antara 200 sampai 700 g/ekor. Rata-rata ini terbagi menjadi tiga kategori yaitu 200 sampai 300 g/ekor, 300 sampai 500 g/ekor, dan 500 sampai 700 g/ekor (Anita 2003).

\section{Rendemen Ikan Layur}

Ikan layur memiliki bobot total rata-rata 250,14 g, dengan rendemen daging dan kulit sebagai bagian tertinggi $(52,44 \%)$. Proporsi rendemen tertinggi kedua yaitu tulang $(26,44 \%)$, sedangkan proporsi rendemen bagian terendah yaitu jeroan (8,36\%). Arifin (2017) menyatakan bahwa ikan layur dengan bobot total rata-rata $338,33 \mathrm{~g}$ memiliki rendemen daging dan kulit 50,19\%, tulang $28,03 \%$, kepala $13,27 \%$, dan jeroan $8,39 \%$. Data ini menunjukkan bahwa rendemen ikan layur meningkat seiring dengan meningkatnya bobot total ikan. Suwandi et al. (2014) menyatakan bahwa proporsi bagian tubuh pada ikan meningkat sesuai dengan ukuran bobot ikan. Menurut War et al. (2011), perbedaan atau peningkatan pada bobot ikan dipengaruhi oleh perbedaan pertumbuhan ikan.

\section{Perubahan Komposisi Kimia Ikan Layur pada Suhu Dingin}

Analisis proksimat pada penelitian ini dilakukan pada ikan segar hari ke-0 (H0), penyimpanan hari k-6 (H6) dan penyimpanan dingin hari ke-10 (H10). Kadar air ikan layur mengalami kenaikan selama proses penyimpanan dingin. Kadar air ikan layur segar hari ke-0 (H0) memililki nilai 77,68\%, hari ke-6 (H6) yaitu 78,88\% dan hari ke-10 (H10) yaitu $80,35 \%$ (Table 2). Kenaikan kadari air yaitu $2,17 \%$. Pandey et al. (2018) melaporkan bahwa terjadi kenaikan kadar air pada ikan makarel selama proses penyimpanan dingin berlangsung. Selama kemunduran mutu laju penurunan $\mathrm{pH}$ otot juga terjadi sehingga menyebabkan terjadi penurunan kemampuan mengikat air dalam bahan (WHC) karena meningkatnya kontraksi antara aktomiosin

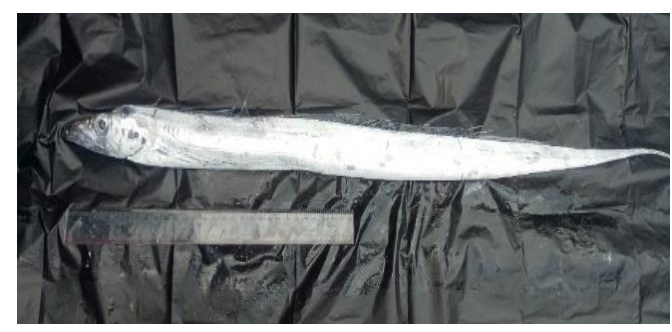

Figure 1 Hairtail fish (Trichiurus sp.) 
Table 1 Morfometrix and average hairtail fish

\begin{tabular}{lll}
\hline Parameters & Unit & Value \\
\hline Total weight & $\mathrm{G}$ & $250.14 \pm 0.07$ \\
Total length & $\mathrm{Cm}$ & $79.64 \pm 0.69$ \\
Wide & $\mathrm{Cm}$ & $1.91 \pm 0.15$ \\
High & $\mathrm{Cm}$ & $5.39 \pm 0.13$ \\
Head length & $\mathrm{Cm}$ & $8.40 \pm 0.21$ \\
\hline
\end{tabular}

Table 1 Morfometrix and average hairtail fish

Tabel 2 Chemical composition of T. lepturus

\begin{tabular}{lcccccc}
\hline \multirow{2}{*}{ Component } & \multicolumn{2}{c}{$\mathrm{H} 0$} & \multicolumn{2}{c}{$\mathrm{H} 6$} & \multicolumn{2}{c}{ H10 } \\
\cline { 2 - 7 } & $(\mathrm{wb})$ & $(\mathrm{db})$ & $(\mathrm{wb})$ & $(\mathrm{db})$ & $(\mathrm{wb})$ & $(\mathrm{db})$ \\
\hline Moisture (\%) & $77.68 \pm 0.25$ & - & $78.88 \pm 0.26$ & - & $80.35 \pm 0.64$ & - \\
Ash (\%) & $1.00 \pm 0.02$ & 4.50 & $0.74 \pm 0.05$ & 3.50 & $0.62 \pm 0.03$ & 3.14 \\
Fat (\%) & $1.07 \pm 0.11$ & 4.80 & $1.26 \pm 0.04$ & 5.97 & $1.57 \pm 0.04$ & 7.46 \\
Protein (\%) & $18.35 \pm 0.57$ & 82.19 & $17.00 \pm 0.49$ & 80.48 & $15.50 \pm 0.46$ & 78.89 \\
Carbohydrate (\%) & $1.90 \pm 0.78$ & 8.50 & $2.12 \pm 0.56$ & 10.05 & $1.97 \pm 0.57$ & 10.51 \\
\hline
\end{tabular}

$\mathrm{H} 0=$ days to storage $0, \mathrm{H} 6=$ days to storage $6, \mathrm{H} 10=$ days to storage

yang terbentuk. Hal ini menyebabkan air bebas pada penyimpanan dapat dengan mudah masuk kedalam jaringan otot. Gultom et al. (2015) menjelaskan bahwa menjelaskan bahwa kandungan air pada ikan umumnya berkisar $70-80 \%$.

Kadar abu pada ikan layur mengalami penurunan selama penyimpanan dingin. Kandungan abu (basis kering=BK) ikan layur segar hari ke-0 (H0) yaitu 4,50\% menurun menjadi $3,50 \% \quad(\mathrm{H} 6)$ dan 3,15\% (H10) (Table 2). Proses penyimpanan suhu dingin menyebabkan penurunan kadar abu yaitu 1,35\%. Mohanty et al. (2016) menyatakan bahwa ikan layur segar yang ditangkap di perairan India dengan berat rata-rata 500$800 \mathrm{~g}$ memiliki nilai abu yaitu $1,6 \%$. Pandey et al. (2018) melaporkan bahwa ikan layur juga mengalami penurunan setelah penyimpanan 12 hari yaitu dari $1,96 \%$ menjadi $1,11 \%$. Daramola et al. (2007) menyatakan bahwa penurunan kadar abu disebabkan karena proses pendinginan yang menyebabkan jaringan otot terhambat dan dipengaruhi juga oleh rasio daging dan tulang pada ikan layur, sedangkan menurut (Garcia-Arias et al. 2003), penurunan abu juga disebabkan oleh aktivitas kulit untuk melelehkan es sehingga terjadi pelepasan abu.

Hasil analisis kadar lemak ikan layur
(Table 2) menunjukkan bahwa kandungan lemak tidak mengalami perubahan secara deskriptif seiring dengan penyimpanan suhu dingin. Kandungan lemak (bk) pada ikan layur segar hari ke-0 (H0) yaitu $4,80 \%$, pada hari ke-6 dan ke-10 berturut-turut menjadi $5,97 \%$ dan $7,46 \%$. Penyimpanan suhu dingin menyebabkan lemak mengalami kenaikan sebesar 2,66\%. Hal ini dikarenakan proses oksidasi yang terjadi selama penyimpanan (Josephson and Lindsay 1987). Mohanty et al. (2016) juga menyatakan ikan layur ( $T$. lepturus) yang ditangkap di perairan india dengan berat rata-rata 500-800 g memiliki nilai total crude fat (BB) yaitu 3,4\%. Perbedaan kandungan lemak dapat dipengaruhi oleh perbedaan spesies, musim dan geografis, umur dan kematangan dalam spesies yang sama (Kumar et al. 2014; Pandey et al. 2018).

Kadar protein ikan layur mengalami penurunan selama penyimpanan dingin 10 hari. Kadar protein ikan layur segar (bk) hari ke-0 (H0) menunjukkan nilai yaitu 82,19\% menurun menjadi 80,48\% (hari ke-6/H6) dan $78,89 \%$ (hari ke-10/H10). Penurunan kadar protein juga terjadi pada ikan kembung selama proses penyimpanan dingin berlangsung (Pandey et al. 2018). Penurunan kadar protein Selama penyimpanan disebabkan karena proses denaturasi (Mc-gill et al. 1974) 
Kandungan karbohidrat ikan layur selama proses penyimpanan dingin berlangsung dan memiliki nilai yang berbeda-beda yaitu $8,50 \%(\mathrm{H} 0), 10,05 \%(\mathrm{H} 6)$ dan $10,51 \%(\mathrm{H} 10)$. Mohanty et al. (2016) yang menyatakan ikan layur yang ditanggkap di perairan India dengan berat rata-rata 500-800 g memiliki nilai total crude carbohydrate (BB) yaitu 1,6\%. Kadar karbohidarat pada ikan layur segar dapat berkisar antara 0,8\% hingga 22,2\% (Bittaret et al. 2012). Kandungan karbohidrat dalam produk perikanan tidak mengandung serat, kebanyakan dalam bentuk glikogen dalam jumlah sedikit berupa glukosa, fruktosa, sukrosa, dan beberapa jenis monosakarida dan disakarida (Nurhayati et al. 2014).

\section{Profil Asam Lemak}

Asam lemak dibagi kedalam tiga jenis yaitu asam lemak jenuh, asam lemak tak jenuh tunggal dan asam lemak tak jenuh jamak (Gibson 1965; Lichtenstein 2005). Hasil analisis asam lemak dapat dilihat Table 3.

Kandungan asam lemak jenuh (SFA) total tidak mengalami perubahan secara deskriptif seiring penyimpanan suhu dingin yaitu $22,58 \%(\mathrm{H} 0)$ dan $24,29 \%$ (H10). Total SFA yang meningkat selama penyimpanan suhu dibawah $0^{\circ} \mathrm{C}$ telah dilaporkan dalam beberapa penelitian misalnya pada ikan red tilapia (Oreochromis niloticus), total SFA meningkat dari $27,12 \%$ hari ke-0 menjadi 28,66\% pada hari ke-30 (Karami et al. 2013), peningkatan total SFA juga terjadi pada ikan makarel (Scomberomorus commersoni) dari $44,20 \%$ (hari ke-0) menjadi 47,56\% (hari ke-30). Perbedaan asam lemak (SFA) pada penyimpanan diakibatkan karena adanya oksidasi lemak yang terjadi pada penyimpanan suhu dingin aktifitas enzim dan gerakan sel terhambat (Handayani et al. 2014). Asam lemak jenuh (SFA) pada layur H0 dan H10 menunjukkan bahwa asam lemak palmitat dan stearat adalah yang paling dominan, sedangkan asam lemak SFA terendah adalah asam heneikosanoik. Asam palmitat dan stearat merupakan jenis asam lemak SFA konsentrasi tertinggi dibandingkan dengan asam lemak lainnya juga dilaporkan dalam beberapa spesies ikan laut (Sahena et al. 2010; Elsdon 2010) misalnya Pseta maxima,
Belone belone, Trichiurus savala, Leiognathus lineolatus (Merdzhanova et al. 2012; Rahayu et al. 2014), dan Abudefduf bengalensisi (Arai et al. 2015).

Asam lemak tak jenuh tunggal (MUFA) merupakan asam lemak yang mengandung ikatan rangkap sebanyak satu pada rantai hidrokarbonnya. Asam lemak tak jenuh tunggal memiliki satu ikatan rangkap karbon yang dapat terjadi pada posisi yang berbeda (Jacoeb et al. 2015). Kandungan asam lemak tak jenuh tunggal (MUFA) total tidak mengalami perubahan secara deskriptif seiring penyimpanan suhu dingin $6-10^{\circ} \mathrm{C}$ berlangsung yaitu dengan nilai $14,34 \%$ (H0) dan 15,52\% (H10). Perbedaan nilai asam lemak yang mungkin terjadi pada 7 jenis asam lemak MUFA ikan layur dapat disebabkan oleh proses oksidasi yang terjadi selama penyimpanan pada lemak (Handayani et al. 2014). Peningkatan total MUFA selama penyimpanan beku telah dilaporkan pada ikan red tilapia (Oreochromis niloticus), dengan total MUFA meningkat dari 14,35\% hari ke-0 menjadi $15,520 \%$ pada hari ke-30 (Karami et al. 2013) dan ikan Rainbow Trout (Oncorhynchus mykiss) dengan kadar total MUFA meningkat dari $31,23 \%$ hari ke-0 menjadi $32,67 \%$ hari ke- 45 . Total MUFA yang tinggi pada beberapa jenis ikan laut, misalnya sea bass (Dicentrarchus labrax) (Bhouri et al. 2010), bluefin tuna (Thunnus orientalis) (Nakamura et al. 2007), dan rainbow trout (Oncorhynchus mykiss) (Testi et al. 2006). Jenis asam lemak tak jenuh tunggal pada didominasi oleh asam oleat dan palmitoleat. Asam oleat merupakan asam lemak esensial. Asam oleat di dalam tubuh berfungsi sebagai sumber energi dan zat antioksidan (Al-Saghir et al. 2004).

Asam lemak tak jenuh jamak (PUFA) adalah asam lemak yang mengandung dua atau lebih ikatan rangkap pada rantai karbon (Sartika 2008). Asam lemak tak jenuh ganda (PUFA), ikatan rangkap pertama dapat ditemukan antara atom karbon ketiga dan keempat dari karbon $\omega$, atau sering disebut asam lemak $\omega-3$ (Omega 3) (Rustan dan Drevon 2005). Kandungan asam lemak PUFA tolal pada penelitian ini berubah seiring dengan penyimpanan dingin yaitu 
Table 3 Profile fatty acid T.lepturus

\begin{tabular}{|c|c|c|}
\hline \multirow[b]{2}{*}{ Fatty Acids } & \multicolumn{2}{|c|}{ Storage (Days) } \\
\hline & $\begin{array}{c}\mathrm{Ho} \\
(\% \mathrm{~W} / \mathrm{W})\end{array}$ & $\begin{array}{c}\mathrm{H} 10 \\
(\% \mathrm{~W} / \mathrm{W})\end{array}$ \\
\hline Lauric Acid, C12:0 & $0.040 \pm 0.014$ & $0.080 \pm 0.028$ \\
\hline Myristic Acid, C14:0 & $1.805 \pm 0.134$ & $2.100 \pm 0.665$ \\
\hline Pentadecanoic Acid, C15:0 & $0.325 \pm 0.106$ & $0.385 \pm 0.092$ \\
\hline Palmitic Acid, C16:0 & $14.165 \pm 1.082$ & $14.925 \pm 1.789$ \\
\hline Heptadecanoic Acid, C17:0 & $0.520 \pm 0.212$ & $0.610 \pm 0.170$ \\
\hline Stearic Acid, C18:0 & $5.250 \pm 1.414$ & $5.610 \pm 1.273$ \\
\hline Arachidic Acid, C20:0 & $0.175 \pm 0.064$ & $0.205 \pm 0.064$ \\
\hline Heneicosanoic Acid, C21:0 & $0.015 \pm 0.021$ & $0.030 \pm 0.014$ \\
\hline Behenic Acid, C22:0 & $0.105 \pm 0.078$ & $0.130 \pm 0.071$ \\
\hline Lignoceric Acid, C24:0 & $0.185 \pm 0.134$ & $0.220 \pm 0.099$ \\
\hline Total SFA & $22.585 \pm 3.260$ & $24.295 \pm 4.207$ \\
\hline Myristoleic Acid, C14:1 & $0.045 \pm 0.021$ & $0.025 \pm 0.007$ \\
\hline Palmitoleic Acid, C16:1 & $2.330 \pm 0.212$ & $2.825 \pm 0.658$ \\
\hline Cis-10-Heptadecanoic Acid, C17:1 & $0.415 \pm 0.120$ & 0.4050 .106 \\
\hline Oleic Acid, C18:1n9c & $10.820 \pm 4.243$ & $11.370 \pm 3.224$ \\
\hline Elaidic Acid, C18: $\ln 9 t$ & $0.070 \pm 0.000$ & $0.095 \pm 0.007$ \\
\hline Cis-11-Eicosenoic Acid, C20:1 & $0.365 \pm 0.049$ & $0.445 \pm 0.106$ \\
\hline Nervonic Acid, C24:1 & $0.300 \pm 0.099$ & $0.355 \pm 0.064$ \\
\hline Total MUFA & $14.345 \pm 4.080$ & $15.520 \pm 2.729$ \\
\hline Linoleic Acid, C18:2n6c & $0.555 \pm 0.134$ & $0.640 \pm 0.099$ \\
\hline Y-Linolenic Acid, C18:3n6 & $0.025 \pm 0.007$ & $0.025 \pm 0.007$ \\
\hline Cis-11, 14-Eicosedienoic Acid, C20:2 & $0.130 \pm 0.028$ & $0.155 \pm 0.021$ \\
\hline Cis-8, 11, 14-Eicosetrienoic Acid, C20:3n6 & $0.145 \pm 0.035$ & $0.150 \pm 0.028$ \\
\hline Arachidonic Acid, C20:4n6 & $3.675 \pm 0.474$ & $3.705 \pm 0.559$ \\
\hline $\begin{array}{l}\text { Cis-5, 8, 11, 14, 17-Eicosapentaenoic Acid, } \\
\text { C20:5n3 (EPA) }\end{array}$ & $3.050 \pm 0.424$ & $3.070 \pm 0.226$ \\
\hline $\begin{array}{l}\text { Cis- } 4,7,10,13,16,19-\text { Docosahexaenoic Acid, } \\
\text { C22:6n3 (DHA) }\end{array}$ & $24.010 \pm 2.121$ & $21.395 \pm 4.673$ \\
\hline Total PUFA & $31.590 \pm 3.224$ & $29.140 \pm 5.303$ \\
\hline Total fatty acids & $68.390 \pm 2.588$ & $68.955 \pm 3.825$ \\
\hline Not identified & $31.610 \pm 2.588$ & $31.045 \pm 3.825$ \\
\hline
\end{tabular}

$31,59 \%$ (H0) menjadi 32,14\% (H10). Selama penyimpanan dingin $6-10^{\circ} \mathrm{C}$ tidak terjadi perubahan asam lemak. Asam lemak PUFA yang terdeteksi pada ikan layur yaitu asam linoleat, Linoleic Acid, Y-Linolenic Acid, Eicosedienoic Acid, Eicosetrienoic Acid, Arachidonic Acid, Eicosapentaenoic Acid (FPA), dan Docosahexaenoic Acid (DHA). Perbedaan nilai asam lemak yang mungkin terjadi pada 7 jenis asam lemak MUFA ikan layur dapat disebabkan oleh proses analisis asam lemak yang kurang efisien. Beberapa penelitian menujukkan bahwa selama penyimpanan suhu frezzing kadar asam lemak PUFA mengalami penurunan disebabkan oleh terjadinya proses oksidasi lemak dan asam lemak selama penyimpanan frezzing (Mendoza et al. 2014). Kandungan asam lemak tertinggi dari asam lemak PUFA adalah jenis asam lemak Docosahexaenoic 
Acid (DHA) yaitu 24\%. Kandungan tertinggi selanjutnya adalah Arachidonic Acid dan Eicosapentaenoic Acid (FPA). Asam lemak tak jenuh ini berperan penting dalam kesehatan tubuh manusia serta merupakan komponen struktural terbesar dalam membran fosfolipid yang mengatur fluiditas membran dan transport ion (Chapkin et al. 2008; Nurjanah et al. 2015; Astiana et al. 2015)

Kandungan asam lemak tak jenuh jamak (PUFA) pada ikan layur memiliki nilai ratarata yang lebih tinggi dibandingkan dengan SFA dan MUFA. Perbedaan ini dipengaruhi oleh faktor habitat dan makanan. Pratama et al. (2011) menjelaskan bahwa komposisi asam lemak tak jenuh majemuk dipengaruhi oleh aksesibilitas makanan dan metabolisme lipid, dan beberapa parameter lingkungan misalnya suhu juga mempengaruhi komposisi asam lemak tak jenuh majemuk. Asam lemak tak jenuh jamak tergolong ke dalam $\omega-3$ dan $\omega-6$ dapat menentukan mutu dan kualitas gizi suatu bahan pangan yang akan dikonsumsi. Rasio omega-6 dan omega-3 fillet ikan layur disajikan pada Table 4.

Nilai omega-3 dan omega-6 ikan segar pada penelitian ini cukup besar yaitu $27,06 \%$ dan $4,25 \%$. Nilai ini berbeda dengan penelitian yang dilakukan Mohanty et al (2016) terhadap ikan layur segar yang ditangkap di India dengan berat rata-rata 500800 yang memiliki nilai omega-3 $1880 \%$ dan omega-6 3,91\% dengan rasio $\omega-3 / \omega-64,80 \%$.
Rasio omega-3 dan omega-6 merupakan indeks yang baik untuk menentukan nilai nutrisi ikan. Rasio $\omega-3 / \omega-6$ penelitian ini menunjukan nilai 6,360\% (H0) dan 5,598\% (H10) (Table 4). Idealnya Rasio $\omega-3$ dan $\omega-6$ dalam konsumsi harian adalah 1:5 atau 1:10 dengan rata-rata mengkonsumsi asam lemak $\omega-6$ yaitu $3-8 \%$ dan $\omega-3$ berkisar $0,5-2,5 \%$ (FAO 1995). Departemen Kesehatan Inggris merekomendasikan rasio ideal $\omega-6 / \omega-3$ yang dapat dikonsumsi maksimum 4. Hasil rasio $\omega$-6 dan $\omega$-3 menujukan nilai $0,157 \%$ (H0) dan $0,178 \%$ (H10) masih dalam batas aman dan layak untuk dikonsumsi (HMSO 1994). Nilai rasio $\omega-6 / \omega-3$ yang lebih tinggi dari batas maksimum berbahaya bagi kesehatan karena dapat memicu penyakit kardiovaskular (Domiszewski et al. 2011).

\section{KESIMPULAN}

Ikan layur mengalami perubahan komposisi kimia pada penyimpan suhu dingin. Nilai total asam lemak baik asam lemak jenuh maupun tak jenuh dapat dipertahankan pada penyimpanan dingin hingga hari ke 10 .

\section{DAFTAR PUSTAKA}

[AOAC] Association of Official Analytical Chemists. 2005. Official Methods of Analysis of The Association of Chemist. Arlington Virginia USA (ID): Publish by The Association of Official Analytical Chemist, Inc.

Table 4 Ratio fatty acids $\omega-3 / \omega-6$ dan $\omega-6 / \omega-3$ T. lepturus

\begin{tabular}{lcc}
\hline \multirow{2}{*}{ Fatty acids } & \multicolumn{2}{c}{ Storage (days) } \\
\cline { 2 - 3 } & Ho (\%) & $\begin{array}{c}\text { H10 } \\
\mathbf{( \% )}\end{array}$ \\
\hline Cis-5, 8, 11, 14, 17-Eicosapentaenoic & 3.050 & 3.070 \\
Acid, C20:5n3 (EPA) & & \\
Cis-4, 7, 10, 13, 16, 19-Docosahexaenoic & 24.010 & 21.395 \\
Acid, C22:6n3 (DHA) & & \\
$\Sigma \boldsymbol{\omega}-3$ & $\mathbf{2 7 . 0 6 0}$ & $\mathbf{2 4 . 4 6 5}$ \\
\hline Arachidonic Acid, C20:4n6 & 3.675 & 3.705 \\
Linoleic Acid, C18:2n6c & 0.555 & 0.640 \\
Y-Linolenic Acid, C18:3n6 & 0.025 & 0.025 \\
$\mathbf{\Sigma} \boldsymbol{\omega - 6}$ & $\mathbf{4 . 2 5 5}$ & $\mathbf{4 . 3 7 0}$ \\
\hline $\boldsymbol{\omega - 3 / \boldsymbol { \omega } - 6}$ & $\mathbf{6 . 3 6 0}$ & $\mathbf{5 . 5 9 8}$ \\
$\boldsymbol{\omega}-\mathbf{6} / \boldsymbol{\omega}-3$ & $\mathbf{0 . 1 5 7}$ & $\mathbf{0 . 1 7 8}$ \\
\hline
\end{tabular}


Abdullah A, Nurilmala N, Sitaresmi KP. 2019. DNA mini-barcodes sebagai penanda molekuler untuk ketertelusuran label pangan berbagai produk ikan layur. Jurnal Pengolahan Hasil Perikanan Indonesia. 22(1): 33-40.

Abdullah A, Nurjanah, Hidayat T, Yusefi Y. 2013. Profil asam amino dan asam lemak kerang bulu (Anadar antiquata). Jurnal Pengolahan Hasil Perikanan Indonesia. 16(2): 159-167.

Abdullah A, Nurjanah, Hidayat T, Aji DU. 2015. Fatty acid profile of jellyfish (Aurelia aurita) as a source raw material of aquatic result rich benefit. International Journal of Chemical and Biomolecular Science. 1(1): 12-16

Abidin Z, Redjeki S, Ambariyanto. 2013. Studi kebiasaan makanan ikan layur (Trichiurus lepturus) di perairan pantai bandengan Kabupaten Jepara dan di perairan Tawang Weleri kabupaten Kendal. Journal of Marine Research. 2(3): 95-103.

Almatsier S. 2006. Prinsip Dasar Ilmu dan Gizi. Cetakan keenam. Jakarta (ID): Gramedia. Al-Saghir S, Thurner K, Wagner KH, Frisch G, Luf W. 2004. Effects of different cooking procedures on lipid quality and cholesterol oxidation of farmed salmon fish (Salmo salar). Journal of Agricultural and Food Chemistry. 52: 5290-5296.

Arai T, Amalina R, Bachok Z. 2015. Fatty acid composition indicating diverse habitat use in coral reef fishes in the Malaysian South China Sea. Biological Research. 48(1): 1-5.

Arifin MF. 2017. Perbedaan suhu proses deep frying terhadap asam lemak, kolesterol, dan jaringan fillet skin on layur (Lepturacanthus savala) [skripsi]. Bogor (ID): Fakultas Institut Pertanian Bogor.

Arpaslan Y, GurelC, Metin C, Hasanhocaoglu H, Baygar T. 2012. Determination of sensory and quality change at treated seabass (Decentrarchus labrax) during cold storage. Journal Food Processing Thechnologi. 3(16): 1-5

Astiana I, Nurjanah, Suwandi R, Suryani AA, Hidayat T. Pengaruh penggorengan belut sawah (Monopterus albus) terhadap komposisi asam amino, asam lemak, kolesterol dan mineral. Depik. 4(1):49-57. [BSN] Badan Standarisasi Nasional. 2013. Ikan Segar. SNI 2729.2013. Jakarta (ID): Badan Standarisasi Nasional Indonesia.

Berghe JP, Barnathan G. 2005. Fatty acids from lipids of marine organisms: molecular biodiversity, roles as biomarkers, biologically active compounds, and economical aspects. Advances Biochemist Enginering/Biotechnol. 96(1): 49-125.

Bhouri AM, Bouhlel L, Chouba L, Hammami M, Cafsi ME, Chaouch A. 2010. Total lipid content, fatty acid and mineral compositions of muscles and liver in wild and farmed sea bass (Dicentrarchus labrax). African Journal of Food Science. 4(8): 522 -530.

Bittaret VT, Awabdi DR, Tonini WCT, Junior MVV, Beneditto APM. 2012. Feeding preference of adult females of ribbonfish Trichiurus lepturus through prey proximate-composition and caloric values. Neotropical Ichthyology. 10(1): 197-203.

Bligh EG, Dyer WJ. 1959. A rapid method of total lipid extraction and purification. Canadian Journal of Biochemistry and Physiology. 37(8): 911-917.

Chapkin R, McMurray D, Davidson L, Patil B, Lupton J. 2008. Bioactive dietary longchain fatty acids: emerging mechanisms of action. British Journal of Nutrition. 100: 1152-1157.

Daramola JA, Fasakin EA, Adeparusi EO. 2007. Changes in physicochemical and sensory characteristics of smoke-dried fish species stored at ambient temperature. African Journal of Food Agriculture Nutrition and Development. 7(6): 1-16.

Domiszewski Z, Bienkiewcz G, Plust D. 2011. Effects of different heat treatment on lipid quality of stripe catfish (Pangasius hypophthalamus). Acta Scientarium Polonorum Technologia Alimentaria. 10(3): 359-377.

Elsdon TS. 2010. Unraveling diet and feeding histories of fish using fatty acids as natural tracers. Journal of Experimental Marine Biology and Ecology. 386: 61-68.

[FAO] Food and Agriculture Organization. 1995. Code of Conduct for Responsible 
Fisheries. Rome (ITL): Food and Agriculture Organization.

Gibson DM. 1965. The biosynthesis of fatty acids. Journal of Chemical Education. 42(5): 236-243.

Gultom OW, Lestari S, Nopianti R. 2015. Analisis proksimat, protein larut air, dan protein larut garam pada beberapa jenis ikan air tawar Sumatera Selatan. Jurnal Teknologi Hasil Perikanan. 4(2): 120-127.

Garcia-Arias MT, Alvarez-Pontes E, Garcia-Fernandez MC, SanchezMuniz FJ. 2003. Freezing/defrosting/ frying of sardine fillets. Influence of slow and quick defrosting on protein quality. Journal of the Science of Food and Agriculture. 83(6): 602-608.

[HMSO] Her Majesty's Stationery Office. 1994. Nutritional aspects of cardiovascular disease (report on health and social subjects No. 46). London (UK): Her Majesty's Stationery Office.

Handayani A, Alimin, Rustiah WO. 2014. Pengaruh penyimpanan pada suhu rendah(freezer- $3^{\circ}$ Cterhadapkandungan air dan kandungan lemak pada ikan lemuru. Alkimia. 2(1): 64-75.

Hidayat T. 2016. Quality deteoration gourame (O. gouramy) during storage. International Journal of Materials Chemistry and Physics. 2(1):40-44

[ITPC] Indonesian Trade and Promotion Center Busan. 2018. Market Beef Fish Consumption. 2016. www.itpc-busan.kr. [5 Mei 2020]

Jacoeb AM, Suptijah P, Kristantina WA. 2015. Komposisi asam lemak, kolesterol, dan deskripsi jaringan fillet ikan kakap merah segar dan goreng. Jurnal Pengolahan Hasil Perikanan Indonesia 18(1): 98-107.

Josephson DB, Lindsay RC. 1987. Retroaldol degradation of unsaturated aldehydes. Journal of American Oil and Chemical Society. 64: 7-9

Karami B, Moradi Y, Motallebi AA, Hosseini E. Soltani M. 2013. Effects of frozen storage on fatty acids profile, chemical quality indices and sensory properties of red tilapia (Oreochromis niloticus, Tilapia mosambicus) fillets. Iranian Journal of Fisheries Sciences. 12(2): 378-388.
Kumar P, Annathai R, Shakila J, Shanmugam SA. 2014. Proximate and major mineral composition of 23 medium sized marine fin fishes landed in the Thoothukudi Coast of India. Journal of Nutrition Food Science. 2(4):1-5.

Lichtenstein AH. 2005. Fats and Oils. Di dalam: Caballero B et al. Encyclopedia of Human Nutrition. Oxford (UK): Elsevier Press.

MacGill AS, Hard R, Burt JR. 1974. Hept-cis-4enal and its contribution to the off flavor in cold stored cod. Journal of Science Food and Agricultural. 25: 1477-1489.

Mendoza CC, Macías JAG, Rojo ADA, Gutiérrez JAO, Licón CH, Flores GC. 2014. Comparison of fatty acid content of fresh and frozen fillets of rainbow trout (Oncorhynchus mykiss) walbaum. Brazilian Archives Biology Technology. 50(1): 103-109.

Merdzhanova A, Stancheva M, Lubomir MAKE. 2012. Fatty acid composition of Bulgarian Black Sea fish species. Ovidius University Annals of Chemistry. 23(1): 4146.

Mohanty PB, Ganguly S, Mahanty A, Sankar TV, Anandan R, Chakrabort K, Paul BN, Sarma D, Dayal JS, Venkateshwarlu G, Mathew S, Asha KK, Karunakaran D, Mitra T, Canda S, Shahi N, Das P, Akhtar MS, Vijayagopal P, Sridha N. 2016. DHA and EPA Content and Fatty Acid Profile of 39 Food Fishes from India. BioMed Research International. 14: 1-14.

Morales R, Arenal AQ, Pimentel R, Mendoza I, Cruz A, Martínez R, Herrera F, Tápanes L, Estrada MP, Fuente DL. 1998. Caracterización del fondo genético de la línea de supertilapias IG/03-F70 I Caracteres morfométricos merísticos y análisis de ADN. Biotecnologia Aplicado. 15: $15-21$

Muhammad AA, Farooq S, Rabbaniha M, Jahangir S, Malik A, Hameed A, Baloch AJ. 2017. Current fishery status of ribbonfish Trichiurus lepturus Linnaeus, (1758) (Trichiuridae) from Makran coast (northeast Arabian Sea). Iranian Journal of Fisheries Sciences. 16 (2): 815-821.

Nakamura I, Parin NV. 1993. Snake mackarels, 
snoeks, escolars, gemfishes, sackfishes, domine, oilfish, cutlassfish, hairtails, and Frostfishes known to date. FAO species catalogue. 15. Rome (ITL): FAO Fish Synop.

Nakamura N, Ando M, Seoka M, Kawasaki K, Tsukamasa Y. 2007. Changes of proximate and fatty acid compositions of the dorsal and ventral ordinary muscles of the full-cycle cultured Pacific bluefin tuna (Thunnus orientalis) with the growth. Food Chemistry. 103: 234-24.

Nurjanah, Suseno SH, Hidayat T, Ekawati Y, Paramudhita P, Arifianto. 2015. Change Composisition chemical of skipjack tuna due to frying process. International Food Research Journal. 2(5): 2093-2102.

Nurjanah, Jacoeb AM, Hidayat T, Ulma RN, Puspitasari, Hidayat T. 2014. Komposisi kimia kupang merah (Musculista senhausia) segar dan rebus. Depik. 3(3): 241249.

Nurhayati T, Salamah E, Cholifah, Nugraha R. 2014. Optimasi proses pembuatan hidrolisat jeroan ikan kakap putih. Jurnal Pengolahan Hasil Perikanan Indonesia. 17(1): 42-52.

[PPN Palabuhanratu] Pelabuhan Perikanan Nusantara Palabuhanratu. 2019. Laporan Tahunan Statistik Pelabuhan Perikanan Nusantara Perikanan Nusantara Palabuhanratu 2003-2017. Pelabuhanratu (ID): PPN Palabuhanratu

Pandey G, Raju CV, Pal G, Pandey HP. 2018. Effect super chilling on the peoximate composition of indian mackarel (Rastreliger kanagurta) stored in solar oprated refrigerated fish finding unit. Journal of Entomology and Zoology Stidies. 6(1): 303-306.

Pratama RI, Awaluddin MY, Ishmayana S. 2011. Analisis komposisi asam lemak yang terkandung dalam ikan tongkol, layur dan tenggiri dari Pameungpeuk, Garut. Jurnal Akuatika. 2(2): 1-10.

Prihatiningsih, Nurulludin. 2014. Biologi reproduksi dan kebiasaan makan ikan layur (Trichiurus lepturus) di sekitar perairan binuangeun, banten. BAWAL. 6 (2): $103-110$
Rahayu SM, Suseno SH, Ibrahim B. 2014. Proximate, fatty acid profile and heavy metal content selected by-catch fish special from Muara Angke, Indonesia. Pakistan Journal of Nutrition. 13(8): 480485.

Rustan AC, Drevon CA. 2005. Fatty acids: structures and properties. Encyclopedia of Life Sciences. 1-7.

Sahena F, Zaidul ISM, Jinap S, Jahurul MHA, Khatib A, Norulaini NAN. 2010. Extraction of fish oil from the skin of Indian mackerel using supercritical fluids. Journal of Food Engineering. 99:63-69.

Sartika RAD. 2008. Pengaruh asam lemak jenuh, asam lemak tidak jenuh dan asam lemak trans terhadap kesehatan. GIZIKESMAS. 2(4): 154-160.

Spikadhara E, Subekti S, Alamsyah MA. 2012. Pengaruh pemberian pakan tambahan (Suplemented fish) dari kombinasi tepung cacing tanah (Lumbricus rubellus) dan tepung Spirulina platensis terhadap pertumbuhan dan retensi protein benih ikan bandeng (Chanos chanos). Journal of Marine and Coastal Science. 1(2): 81-90.

Suwandi R, Nurjanah, Margaretha M. 2014. Proporsi bagian tubuh dan kadar proksimat ikan gabus berbagai ukuran. Journal Pengolahan Hasil Perikanan Indonesia. 17 (1): 1-5.

Testi S, Bonaldo A, Gatta, PP, Badiani A, 2006. Nutritional traits of dorsal and ventral fillets from three farmed fish species. Food Chemistry. 98: 104-111.

Tuminah S. 2009. Efek asam lemak jenuh dan asam lemak tak jenuh "trans" terhadap kesehatan. Media Peneliti dan Pengembangan Kesehatan. 15: 13-20.

Vianita R, Saputra SW, Solichin A. 2014. Aspek biologi ikan layur (Trichiurus lepturus) berdasarkan hasil tangkapan di ppp morodemak. Diponegoro Journal of Maquares. 3(3): 160-167.

War M, Altaff K, Abdulkhader HM. 2011. Growth and survival of larval snakehead Channa striatus (Bloch 1793) fed different live feed organisms. Turkish Journal of Fisheries and Aquatic Sciences. 11(9): 523 528. 